\title{
Infectious Hepatitis B Negatively Impacts Lifestyles of Affected Individuals in Ejura-Sekyedumasi District of Ghana
}

Benjamin Makimilua Tiimub ${ }^{1 *}$, Beloved Mensah Dzomeku ${ }^{3}$, Gideon Likida Tiimob ${ }^{4}$, Richard Tandoh ${ }^{2}$, Ernestina Laatman Tiimob ${ }^{5}$, Foster Dokin Nyapkaab ${ }^{6}$, Joan Jackline Agyenta ${ }^{7}$, Isaac Baani ${ }^{2}$ and Elisha Nyannube Tiimob $^{8}$

${ }^{1}$ Department of Environmental Engineering, College of Environmental and Resource Sciences, Zhejiang University, Hangzhou, 310058, P.R. China

${ }^{2}$ Department of Environmental Health and Sanitation Education, Faculty of Environment and Health Education, University of Education, Winneba, Ashanti-Mampong Campus, Ghana.

${ }^{3}$ Principal Research Scientist, Crops Research Institute, CSIR, Fumesua, Kumasi, Ghana

${ }^{4}$ Public Health Specialist (CE4MCH- Supervisory Section), Catholic Relief Services (CRS), Tamale, Ghana.

${ }^{5}$ Business Senior High School (BISCO), Tamale, N/R, Ghana

${ }^{6}$ Northern Business Senior High School (NOBISCO), Tamale, N/R, Ghana

${ }^{7}$ Nibrasiya Islamic Basic School, GES, Techiman, Bono East Region, Ghana

${ }^{8}$ Department of Ports and Shipping, Regional Maritime University, Nungua-Greater Accra Region, Ghana

\begin{tabular}{|c|c|}
\hline $\begin{array}{c}\text { Article History } \\
\text { Received: } 03.10 .2020 \\
\text { Accepted: } 22.10 .2020 \\
\text { Published: } 30.10 .2020 \\
\text { Journal homepage: } \\
\text { https://www.easpublisher.com/easjpid } \\
\text { Quick Response Code }\end{array}$ & $\begin{array}{l}\text { Abstract: Infectious hepatitis b virus (HBV), currently a common disease of the world is } \\
\text { entangling over two billion susceptible individuals intimated with } \geq 400 \text { million chronicity } \\
\text { cases. HBV induces higher mortality, morbidity, financial burden, constituting major global } \\
\text { health threat to any human race. Previous studies hinted that high prevalence of HBV } \\
\text { infections in Ghana, negatively affect individuals and communities at large. This timely } \\
\text { case study purposively cross-examined the impact of HBV on individual patients and } \\
\text { community as a whole at the Ejura-Sekyedumasi district hospital. The designed survey } \\
\text { involved } 36 \text { randomly selected HBV infected patients been pooled from hospital records to } \\
\text { willingly offer information under purposive sampling technique using already pretested } \\
\text { questionnaires that scored } \geq 95 \% \text { veridicality. The findings revealed deleterious effects of } \\
\text { HBV by juxtaposing percentage infection, morbidity, debilitation rates on the reduced living } \\
\text { standards among patients which specifically engrossed: obnoxious stigmatization (50- } \\
61.1 \% \text { ); inability to [afford three square meals ( } \geq 55.6 \%) \text {; pay utility bills ( } \geq 69.4 \%) \text {; save } \\
\text { money ( } \geq 80.6 \% \text { ); pay medical bills }(\geq 58.4 \%)] \text {; risk of dismissal from work ( } \geq 61.1 \%) \text {; } \\
\text { poor relationships and neglect ( } 41.7 \% \text { and } 13.9 \%) \text {; ineffective participation in community } \\
\text { functions ( } \geq 58.3 \% \text { ); and fear of cross infection }(\geq 94.4 \%) \text {. The study recommends joint } \\
\text { actions of religious bodies, healthcare service providers, public health education advocates } \\
\text { elucidating causes, effects, early screening and vaccination interventions against HBV. State } \\
\text { media institutions should be educating communities on proper management of HBV while } \\
\text { reproaching neglect and stigmatisation, projecting pre-marital counselling or screening to } \\
\text { counteract the disease. } \\
\text { Keywords: Ejura-Sekyedumasi, Hepatitis B, Infection, Community health, Education. }\end{array}$ \\
\hline
\end{tabular}

Copyright ( $) 2020$ The Author(s): This is an open-access article distributed under the terms of the Creative Commons Attribution 4.0 International License (CC BY-NC 4.0) which permits unrestricted use, distribution, and reproduction in any medium for non-commercial use provided the original author and source are credited.

\section{INTRODUCTION}

The Hepatitis B virus (HBV) belonging to the hepadnavirus family, is a small circular DNA virus containing an enveloped nucleocapsid that contains a relatively small and incompletely double stranded 3.2 $\mathrm{Kb}$ DNA genome, viral polymerase and core protein [1]. Its envelope is composed of viral surface proteins enclosed with a lipid membrane from host cells. In the serum of infected patients, there are both mature virions with viral DNA and sub-viral particles without viral DNA. The HBV infection is deleterious illness which damages the liver of hominodea, including humans, and causes an inflammation called hepatitis. Acute illness causes liver inflammation, vomiting, jaundice and in most cases death [2]. Chronic hepatitis B may eventually cause liver cirrhosis and liver cancer. Hepatitis B virus primarily interferes with the functions of the liver by replicating itself in the liver cells, known as hepatocytes. Hepatitis B virus spreads faster than the human immunodeficiency virus (HIV) that causes AIDS [2].

Transmission of hepatitis B virus cross infection results from exposure to infectious blood and body fluids containing blood, sexual contact, blood transfusion, re-use of contaminated needles and 
syringes and vertical transmission from mother to child during childbirth [3]. Without intervention, a mother who is positive for hepatitis B confers about $20 \%$ risk of passing the infection to her off spring at the time of birth and the risk is as high as $90 \%$ if the mother is also positive to $\mathrm{HBV}[4,5]$. Hepatitis $\mathrm{B}$ virus can be transmitted between family members within household possibly by contact of non-intact skin or mucus membrane with secretions or saliva containing hepatitis B virus although; at least $30 \%$ of reported hepatitis B among adults cannot be associated with an identifiable risk factor [2].

Adults' hepatitis B virus prevalence is estimated between $12-18 \%$ in Ghana [6]. The prevalence of hepatitis B virus co-infection has been around $17 \%$ in Kumasi (hepatitis B virus positive cohort), whereby about $95 \%$ of the infections are due to genotype E, and $74 \%$ of co-infected patients are $\mathrm{HBsAg}$ negative [7]. Hepatitis B surface antigen (HBsAg) technique is the most frequently used to screen for the presence of the infection. It is the first detectable viral antigen to appear during infection [8]. According to a study in two Gambian villages, it showed that, horizontal transmission is predominant in Africa of which $10 \%$ mothers tested positive to HBsAg [9].

- Infection is not common within first year of life.

- $50 \%$ of the children are affected by the age of five.

- By age ten, almost everybody is infected, (15$20 \%$ ) been chronic careers [10].

Several vaccines have been developed by scientists for the prevention of hepatitis B infection. They rely on the use of the one viral envelope proteins (HBsAg) for the vaccination against the hepatitis B virus [11]. Acute hepatitis B infection does not usually require treatment because most adults clear the infection spontaneously [5]. On the other hand, treatment of chronic infection may be necessary to reduce the risk of cirrhosis and liver cancer. Although none of the available drugs can clear the infections, they can stop the virus replication [2]. Increased liver cirrhosis related death which is caused by hepatitis B and hepatitis $\mathrm{C}$ infection is becoming alarming in EjuraSekyedumasi District of the Ashanti Region which characterized by chronic consumption of alcoholic beverages compared to elsewhere among the Indians [12].

For the past decade, hepatitis B has become a serious public health issue in Ghana due to high media publicity and increased health education. Also, for these past years Non- Governmental Organizations (NGOs) and corporate bodies have joined hands in various activities to fight the disease incidence through screening and vaccination [13]. Public health burden of HBV infection in Ghana is unknown, although the country has long been considered to be among the highly endemic countries of sub-Saharan Africa with more than $8 \%$ of the population suspected to harbour chronic infection which has the potential to rapidly spread [5, 11, 3]. Results from a few Ghanaian studies have supported this hypothesis: the prevalence of HBV surface antigen (HBsAg), a marker of chronic HBV infection, ranged from 6 to $15 \%$ among blood donors when HBV screening was earlier introduced among selected populations in Ghana and monitored through various updated clinical reports [14, 7, 4, 13]. Among the medical students and health workers, prevalence of HBsAg was previously detected (ranged from 8 to $11 \%$ ) and was very common among blood donors in Sierra Leone and Ghana [15, 16, 7]. In regions of high endemicity, HBV is mainly contracted at birth or during early childhood [17]. The development of chronic HBV infection occurs in approximately $90 \%$ of persons infected perinatally, 30\% infected in early childhood and $6 \%$ infected after 5 years of age [18]. Persons with chronic HBV infection have a $15-25 \%$ risk of dying prematurely in adulthood from HBV related cirrhosis and hepatocellular carcinoma, and acutely infected individuals occasionally succumb to fulminant liver failure [17]. Like HIV, people who are infected with the virus are stigmatized. In some cases, they are expelled from work. This invariably affects productivity to the extent of affecting their finances to access quality medical care. In some parts of the world, some hepatitis $\mathrm{B}$ patients have complained of having problem with finances which eventually impacts negatively on their living standards [19]. It is against this background that this study investigated the socio-economic impact of hepatitis B from community-based hospital diagnostic records of infected individuals who were identified to be receiving medical attention at the Ejura Hospital in the Ashanti Region of Ghana.

\section{Problem identified and justification and purpose of the study}

For the past few years, some hepatitis B infected persons have complained of stigmatization and lack of financial support from family members and other people in endemic communities [20]. That is the more reason why there was the need to conduct a tailored study to assess the impact of hepatitis B on an individual patient and the community as a whole.

The issue of the rampant spread and associated threat of the Hepatitis B virus has over the past decade become a worldwide concern as the infection and death rates keep increasing, especially in endemic countries. The virus has been identified to be the cause of an estimated seven hundred thousand deaths in the world, annually, with Ghana hotly spotted from previous HBV recurring trends [3]; and currently ranks as one of the countries in sub-Saharan Africa that is susceptible to the spread of the HBV infections [11]. The social and economic lifestyle of the people of the EjuraSekyedumasi district, compared to available literature on effect of the virus on the individual, strongly 
motivated the authors to undertake this study to verify the socio-economic impact of HBV on the individual and the community as a whole. The study mainly determined the impact of hepatitis $\mathrm{B}$ on the individual patients and the community at Ejura-Sekyedumasi District in the Ashanti Region by specifically finding out about: 1. living condition of the people infected with hepatitis B before and after infection; 2 . relationship between the people living with hepatitis B and the community before and after the infection; 3.type of work done by the people living with hepatitis $\mathrm{B}$ before and after infection; 4. the financial status of individual with hepatitis $B$ before and after the infection, and 5. how HBV infections affect the community under the following key research questions:

- What are the current living conditions of people infected with hepatitis B?

- What is the relationship between people living with hepatitis B and other community members?

- What type of work do people living with hepatitis B do?

- What is the financial status of the individual with hepatitis B before and after infection?

- How does the disease affect the community members particularly in terms of the deleterious effects cast particularly on the HBV infected patients?

\section{Significance, scope and limitations of the study}

The study offered the opportunity to determine the impact of hepatitis B and make recommendations for implementation of community and hospital-based health intervention programmes. The key findings feed stakeholders in the health sector with adequate information on the level of public awareness on the impacts of the deadly virus and possible interventions that could be scaled to minimize spread of the HBV. The actual impacts of HBV on lifestyles factors that predispose citizens to high risk of HBV infection were examined for proper attention and education to reduce stigmatization. The recommendations could help in designing programmes to aid the campaigns directed against rapid spread of the virus in the Ejuraman district. The study was limited to assessment of socioeconomic impact of hepatitis B on infected individual in Ejura-Sekyedumasi District. The focus or target group was only infected patients reporting to the EjuraSekyedumasi District Hospital. Due to financial constraints the researchers could not consult infected persons regularly. Some infected persons were also not willing to divulge the needed information. It was very difficult to contact some patients due to the nature of their work. The study involved a lot of risk since the researcher had to travel a lot to fish out information from the target population.

\section{LITERATURE \\ History of hepatitis B}

More than 2 billion people worldwide are estimated to have had hepatitis B virus (HBV) infection and 350 million chronic carriers of the virus are at high risk of cirrhosis of the liver and primary liver cancer $[21,5]$. HBV accounts for an estimated 500,000700,000 annual deaths worldwide. With a safe and effective vaccine available since 1982, much of this infection and death should be preventable. Although there are many ways of passing on $\mathrm{HBV}$, the virus actually is not very easily transmitted. There is no need to worry that casual contact, such as shaking hands, will expose one to hepatitis $\mathrm{B}$. There is no reason not to share a workplace or even a restroom with an infected person [22].

More than 300 million persons throughout the world are infected by HBV over the years. While most people who become chronic carriers of the virus live in Asia and Africa, there are no fewer than 1.5 million carriers in the United States [23]. Because carriers represent a constant threat of transmitting the infection, the risk of hepatitis B is always highest where there are many carriers among different specific age groups. Such areas are said to be endemic for hepatitis B [24]. Also, when infants or young children living in an endemic area are infected, their chance of becoming a chronic hepatitis B carrier is at least $90 \%$, probably because their bodies are not able to make the substances (antibodies) that destroy the virus [4, 25]. In contrast, no more than $5 \%$ of infected teenagers and adults develop chronic infection [26, 3,27].

\section{Definition of hepatitis}

Hepatitis may be caused by viruses or by medicines or alcohol. Hepatitis has the following forms: Hepatitis A, B, C, D and E [28]: Hepatitis B: A virus commonly spread by sexual intercourse or blood transfusion or from mother to newborn at birth. Another way it spreads is by using a needle that was used by an infected person. Hepatitis B is more common and much more easily spread than the AIDS virus and may lead to cirrhosis and liver cancer [9]. Hepatitis B which is a potentially serious form of liver inflammation due to infection by the HBV, occurs in both rapidly developing (acute) and long-lasting (chronic) forms, and is one of the most common infectious diseases worldwide [7]. But an effective vaccine is available that will prevent the disease in those who are later exposed [29].

\section{Description}

Commonly called "serum hepatitis," hepatitis B ranges from mild to severe. Some people who are infected by HBV develop no symptoms and are totally unaware of the fact, but they may carry HBV in their blood and pass the infection on to others. In its chronic form, HBV infection may destroy the liver through a 
scarring process, called cirrhosis, or it may lead to cancer of the liver [17]. When a person is infected by $\mathrm{HBV}$, the virus enters the bloodstream and body fluids, and is able to pass through tiny breaks in the skin, mouth, or the male or female genital area. There are several ways of getting the infection:

- During birth, a mother with hepatitis B may pass HBV on to her infant $[11,30]$.

- Contact with infected blood is a common means of transmitting hepatitis B. One way this may happen is by being stuck with a needle. Both health care workers and those who inject drugs into their veins are at risk in this way $[14,31]$.

- Having sex with a person infected by HBV is an important risk factor (especially anal sex) [32].

Hepatitis is the inflammation of the liver of variable severity producing a clinical illness which results in hepatocellular damage and destruction. It is caused by hepatitis B virus. With the exception of $\mathrm{HBV}$, all the common viruses that cause hepatitis are known as RNA viruses because they contain ribonucleic acid or RNA as their genetic material. HBV is the only deoxyribonucleic acid (DNA) virus that is a major cause of hepatitis. HBV is made up of several fragments, called antigens that stimulate the body's immune system to produce the antibodies that can neutralize or even destroy the infecting virus. It is, in fact, the immune reaction, not the virus, that seems to cause the liver inflammation [11].

Hepatitis B virus is a DNA double stranded with single stranded regions enveloped hepadnavirus. The hepadnavirus is about $42 \mathrm{~nm}$ and is icosahedra. The virus is often referred to as Dane particle [33]. HBV contains surface glycoprotein designated as hepatitis B surface antigen (HBsAg) which makes up envelope proteins. Its presence in serum denotes active infection. It consists of a mass core encodes polypeptides that expressed as hepatitis B ellipse antigen ( $\mathrm{HBeAg}$ ) and viral capsid protein called hepatitis $\mathrm{B}$ core antigen (HBcAg). HBsAg in blood denotes an onset and acute infection or carriers of $\mathrm{HBV}$. HBeAg correlates with high infectiousness. Anti HBs confer immunity to $\mathrm{HBV}$. HBclAg is found in hepatocytes and is not easily detected in serum [34]. Anti-HBcIgM appears in recent infection up to six months. Anti HBcIgM appears in screening of infections beyond six months. Anti $\mathrm{Hb}$ appears shortly after resolution of acute infection. HBV DNA detects infectivity the incubation period of HBV is between two to six months [34]. A major breakthrough in the understanding of viral hepatitis occurred on the detection of "Australia antigen" in the blood of an Australian aborigine by Blumberg in 1965 . This was subsequently recognized to be the hepatitis B surface antigen [35].
HBsAg could be present in blood, semen, vaginal secretion, saliva, breast milk, bile, and amniotic and ascetic fluid. Hepatitis B can be transmitted through parenteral or percutaneous that is through blood and blood products. Injection with contaminated needles, dental extraction, operation, tattooing, acupuncture needles, ear-piercing and using of an infected toothbrush can also lead to the transmission of the virus [8]. It can also be transmitted through Vertical or perinatal that is from an infected mother to infant [11]. This normally occurs during the last trimester of pregnancy or birth. HBV is also transmitted through venereal or permucosal. This infection is common among homosexuals and heterosexuals due to anal intercourse with multiple partners, resulting in rectal mucosal injury and spread HBV [2]. It can also be transmitted through oral-oral spread. Since HBsAg is present in saliva, deep kissing and mouth pipetting may also be oral method of transmission [36].

\section{Percentage rate of hepatitis $B$ infection}

Globally, hepatitis B infection is more prevalent in males with prevalence rate of $7.2 \%$ than in females with prevalence rate of $4.3 \%$. When comparing the prevalence rates across age groups, there is a relatively high infection rates across all the age brackets, though those aged 21-30 were more likely to be infected followed by those aged 11-20 years [10]. Hepatitis B virus occurs worldwide, and highest $\mathrm{HBsAg}$ carrier rates are found in developing countries with limited medical facilities [3].

The prevalence of chronic $\mathrm{HBV}$ infection is low $(<2 \%)$ in the general population in Northern and Western Europe, North America, Australia, New Zealand, Mexico, and southern South America. The prevalence of chronic HBV infection is intermediate $(2 \%-7 \%)$ in South, Central, and Southwest Asia, Israel, Japan, Eastern and Southern Europe, Russia, most areas surrounding the Amazon River basin, Honduras, and Guatemala. The prevalence of chronic HBV infection is high $(\geq 8 \%)$ in all socioeconomic groups in Africa; Southeast Asia, including China, Korea, Indonesia, and the Philippines; the Middle East, except Israel; South and Western Pacific islands; the interior Amazon River basin; Haiti and the Dominican Republic [37]. The prevalence is lowest in countries with the highest living standard, such as Great Britain, Canada, United States, Scandinavia and some other European nations. In moderate prevalence areas where $2-7 \%$ of the population is chronically infected, the disease is predominantly spread among children. In high prevalence area such as China and South East Asia, transmission during child birth is most common. The prevalence of chronic HBV infection in areas of high endemicity is at least $8 \%$ [10].

\section{Practices that leads to hepatitis B transmission}

Although blood transfusion saves millions of lives worldwide each year, recipients of transfusions are 
at high risk of becoming infected with blood-borne pathogens [6]. Each year, up to 4 million blood donations worldwide are not tested for human immunodeficiency virus (HIV) and few are tested for hepatitis $\mathrm{B}$ and $\mathrm{C}$ viruses (HBV and $\mathrm{HCV}$, respectively) [16]. Virtually none are screened for human T-cell lymphotrophic virus type 1 (HTLV-1) or Treponema pallidum, the causative agent of syphilis [38]. Several studies have previously indicated the level of neglect but high prevalence of $\mathrm{HBV}$ in Ghana among other Sub-Saharan African countries, and pre-screening of blood donors for HBV surface antigen ( $\mathrm{HBsAg}$ ) is thus a routine practice [17].

Ghana has long been considered to be among the highly endemic countries of sub-Saharan Africa with more than $8 \%$ of the population suspected to harbour chronic infection [13]. The review included 21 studies across all ten old regions of Ghana with a total sample population of 29061 showing recently that the burden of hepatitis B is enormous and remains an important public health issue in Ghana. The HBV prevalence was estimated for subpopulations as follows: $8.36 \%$ in the adult population, $14.30 \%$ in the adolescent population, and $0.55 \%$ in children under five years (preschool). Among adults, HBV infection prevalence was the highest in the special occupation group (14.40\%) and the lowest prevalence rate of $7.17 \%$ was recorded among blood donors. Prevalence was lower in the north than in the southern part of the country. The Ashanti region had the most studies at $6 / 21$ (29\%), while no study was identified for the Upper West region. Across the country, the highest HBV infection prevalence rates were recorded in the age group of 20-40 years [13]. This confirms earlier findings on sero-prevalence of hepatitis B in cirrhosis of the liver in Korle-Bu Teaching Hospital. Moreover, HBsAg was detected in 30 out of 70 cases, giving a prevalence rate of $42.9 \%$ [39]. Adult HBV prevalence was earlier estimated between $12-18 \%$ in Ghana when the prevalence of HBV co-infection was $17 \%$ in Kumasi among HIV positive cohorts [13].

\section{Level of knowledge about hepatitis B}

Only $70 \%$ male and $30 \%$ female stated that hepatitis B is a major public health problem in EjuraSekyedumasi District. The difference between the sexes was significant. The majority of the study population participants knew that hepatitis B is a viral disease and primarily affects the liver and can be transmitted by unsterilized needles and surgical instruments, however they had poor knowledge about transmission risks related to contaminated blood, tattooing, deep kissing which leads to exchange of blood if there is presence of cut and its effect [2].

\section{Types of hepatitis B \\ Acute hepatitis B}

In the United States, a majority of acute HBV infections occur in teenagers and young adults. Half of these youth never develop symptoms, and only about $20 \%$ - or one in five infected patients - develop severe symptoms and yellowing of the skin (jaundice). Jaundice occurs when the infected liver is unable to get rid of certain colored substances, or pigments, as it normally does [3]. The remaining $30 \%$ of patients have only "flu-like" symptoms and will probably not even be diagnosed as having hepatitis unless certain tests are done. The most common symptoms of acute hepatitis B are loss of appetite, nausea, generally feeling poorly, and pain or tenderness in the right upper part of the abdomen (where the liver is located). Compared to patients with hepatitis $\mathrm{A}$ or $\mathrm{C}$, those with $\mathrm{HBV}$ infection are less able to continue their usual activities and require more time resting in bed. Occasionally patients with HBV infection will develop joint swelling and pain (arthritis) as well as hives or a skin rash before jaundice appears. The joint symptoms usually last no longer than three to seven days [40]. Typically, the symptoms of acute hepatitis B do not persist longer than two or three months. If they continue for four months, the patient has an abnormally long-lasting acute infection. In a small number of patients - probably fewer than $3 \%$ - the infection keeps getting worse as the liver cells die off. Jaundice deepens, and patients may bleed easily when the levels of coagulation factors (normally made by the liver) decrease. Large amounts of fluid collect in the abdomen and beneath the skin (edema). The least common outcome of acute HBV infection, seen in less than $1 \%$ of patients, is fulminate hepatitis, when the liver fails entirely. Only about half of these patients can be expected to live [2].

\section{Chronic hepatitis B}

HBV infection lasting longer than six months is said to be chronic. After this time, it is much less likely for the infection to disappear [17]. Not all carriers of the virus develop chronic liver disease. In fact, a majority has no symptoms. But, about one in every four HBV carriers develop liver disease that gets worse over time, as the liver becomes more and more scarred and less able to carry out its normal functions [14]. A badly scarred liver is called cirrhosis. Patients are likely to have an enlarged liver and spleen, as well as tiny clusters of abnormal blood vessels in the skin that resemble spiders. The most serious complication of chronic HBV infection is liver cancer. Worldwide this is the most common cancer to occur in men. Nevertheless, the overall chance that liver cancer will develop at any time in a patient's life is probably much lower than $10 \%$. Patients with chronic hepatitis B who drink or smoke are more likely to develop liver cancer [2]. It is not unusual for a person to simultaneously have both HBV infection and infection by HIV (human immunodeficiency virus, the cause of AIDS) [42]. A previous study released in 2003 reported that men infected with both HIV and HBV were more likely to die from liver disease than people infected with just one of the diseases [43]. 


\section{Diagnosis}

Hepatitis B is diagnosed by detecting one of the viral antigens - called hepatitis B surface antigen (HBsAg) - in the blood. Later in the acute disease, HBsAg may no longer be present, in which case a test for antibodies to a different antigen - hepatitis B core antigen - is used. If HBsAg can be detected in the blood for longer than six months, chronic hepatitis B is diagnosed [11]. A number of tests can be done to learn how well, or poorly, the liver is working. They include blood clotting tests and tests for enzymes that are found in abnormally high amounts when any form of hepatitis is present [2].

\section{Treatment}

In the past, there was no treatment available for hepatitis B. But developments have been made in recent years on drugs that suppress the virus and its symptoms. In early 2003, a drug called adefovir was reported as an effective treatment. Another drug called tenofovir was demonstrated as effective in patients infected with both hepatitis B and HIV. Two studies also reported on the effectiveness of a drug called Preveon, which was more expensive than others. Patients also should rest in bed as needed, continue to eat a healthy diet, and avoid alcohol [43]. Any noncritical surgery should be postponed. The best way to prevent any form of viral hepatitis is to avoid contact with blood and other body fluids of infected individuals. The use of condoms during sex also is advisable. If a person is exposed to hepatitis $B$, a serum preparation containing a high level of antibody against HBV may prevent infection if given within three to seven days of exposure. Babies born of a mother with HBV should receive the vaccine within 24 hours [43]. An effective and safe vaccine is available that reliably prevents hepatitis B. Vaccination is suggested for most infants and for children aged 10 and younger whose parents are from a place where hepatitis B is common. Teenagers not vaccinated as children and all adults at risk of exposure also should be vaccinated against hepatitis B. Three doses are recommended [18].

\section{Definition of terms [11, 2, 43]}

- Antibody-A substance formed in the body in response to a foreign body, such as a virus, which can then attack and destroy the invading virus.

- Antigen- Part of an invading microorganism, such as a virus, that causes tissue damage (in hepatitis, to the liver), and that also stimulates the body's immune system to produce antibodies.

- Cirrhosis- The end result of many forms of liver disease, the condition of the liver when its cells have been damaged or destroyed and are replaced by scar tissue.

- Vaccine- A substance prepared from a weakened or killed virus which, when injected, helps the body to form antibodies that will attack an invading virus and may prevent infection altogether. Those at increased risk of getting hepatitis $\mathrm{B}$, are those who therefore should be vaccinated to prevent infection or contraction of the disease.

\section{METHODOLOGY}

Study area location and size, topography and drainage and religious background of respondents

Ejura-Sekyedumasi District was carved out of the former Sekyere and Offinso Districts and was thus created as a result of the implementation of the decentralized programs on 29th November, 1988. The district was established by a legislative instrument. The district is located within longitudes $1^{\circ} 5 \mathrm{~W}$ and $1^{\circ} 39^{\prime} \mathrm{W}$ and latitudes $7^{\circ} 9^{\prime} \mathrm{N}$ and $7^{\circ} 36^{\prime} \mathrm{N}$. It has a large land size of about 1,782.2sq.km (690. 781sq.miles) and is the fifth largest district in Ashanti region's 21 districts. It constitutes about $7.3 \%$ of the region's total land area with about one third of its land area lying in the Afram Plains. It is located in the Northern part of the Ashanti Region and is bounded in the north by Atebubu and Nkoranza districts (both in the Bono East Region), on the west by Offinso District, on the East by Sekyere East District and the south by Sekyere West and Afigya Sekyere Districts.

The landscape in the southern part of the district is fairly surrounded by valleys and peaks. Averagely, the valleys have a depth of about $135 \mathrm{~m}$ whilst the peaks rise to about $315 \mathrm{~m}$ above sea level (District Profile). The highest point in the district is made up of a range of hills, found in the eastern part and passes through Ejura and Mampong, forming part of the Kintampo-Koforidua range. Examples of the hills found in the district include; Kwasi Mahu Hills $(1,350)$, Ejurachem Scarp $(1,000)$ and Dente Scarp (rock outcrop) with a greater part of the district reserve being a scarp. The northern part is undulating and fairly flat with heights ranging between $150-300 \mathrm{~m}$. Ejura is located on an altitude of about $225 \mathrm{~m}$. The district is dissected and well-drained by a number of rivers, streams and their tributaries. The drainage is dendritic in nature and has a west-east and northwest-southeast directional flow. Major rivers include; Affram, Akobaa, Chirade, Bresua whilst minor ones include Aberewa, Yaya and Baba. About $60 \%$ of the inhabitants in EjuraSekyedumasi district are Muslims, 30\% are Christians and the remaining $10 \%$ are traditional worshipers. The former religion allows polygamy with many sexual partners to one man in sexual relationship which facilitates the spread of sexually transmitted infectious diseases such as HBV infection.

\section{Research design and sampling techniques and sample size}

The research was entirely an action-oriented case study that assessed the impact of Hepatitis B on individual patient in the selected communities. The main instrument designed for the data collection was a 
questionnaire; literate respondents were able to fill the questionnaire by themselves while the illiterates were assisted by the researcher. The instrument had some strengths - It sequestered accurate and confidential information about the respondent, and facilitated valid and reliable information gathering within a limited time frame. Hence, information suggested by respondents was not influenced in anyway. However, a major challenge faced by the researcher was that, he had to chase some subjects hitherto in the process of questionnaire retrieval regardless that some literate respondents could not also clearly provide adequate answers in the spaces provided for the open type questions. High level of the independent valid responses suggested reflected a true picture of the impact of hepatitis $\mathrm{B}$ on the individual patients and their community. Gender sensitive responses were targeted amongst the entire randomly HBV patients encountered from the hospital at the time of the purposive survey in Ejura-Sekyedumasi district by tracking the unique details of the gender status (sex and age groups) as well as the religious background of the study population.

Stratified sampling technique was employed for the general study population in the selection of information donors. The size of the District and the Sub-District was considered during sampling. Ejura was the largest followed by Sekyedumasi and Kasei in terms of regular information donors. The total number of HBV infected patients in Ejura, Sekyedumasi and Kasei were: 24, 16 and 10 respectively. Within each SubDistrict or District, stratified sampling was conducted using secondary data based on similar previous hospital-based research designs. For convenience and cost effectiveness, details of the patients were collected from the primary data of the outpatient department records section by ensuring that up to forty percent of the representative patients was selected from each community for the study. Thus, 16 out of 42 from Ejura, 12 out of 36 from Seko and 8 out of 25 from Kasei were the HBV patients who constituted the background respondents in the survey with a total sample population size $(\mathrm{N}=36)$.

\section{Instrument for data collection, questionnaire administration and data analyses}

The major instrument in collecting data for the study comprised a questionnaire tagged "effect of hepatitis B on the individual and the community as a whole". The questionnaire was used to ensure easier collection of data from a fairly large population. All the questions were numbered to make it easier for the respondents to follow. Structured close-ended questions were used, because they are economical to handle in terms of time and money alongside few open-ended questions. Ten questionnaires were pretested to ensure high verification and it attracted $97 \%$ retrieval and valid response rates before commencing with the main survey. Entirely, 29 closed and open-ended test items were developed. Whereas literate respondents were allowed to complete the questionnaires independently, their illiterate counterparts were asked the questions in the questionnaire and the researcher filled in the suggested answers for them. Some questionnaires were given to the respondents to independently answer for later collection. There was about $96 \%$ retrieval with valid response rate. The raw questionnaires data were collected and entered manually into excel and transformed into tables, and percentages using Statistical Package for Social Sciences (SPSS - Chicago Version 16.0) for the analyses. The results were transformed into frequency and percentage distribution tables for easy interpretation and adoption by target beneficiaries such as health workers, civil society organizations, community development partners, NGOs and academic institutions. The frequency/percentage distributed data tables presented the weighted scores on how the key responses occurred against the questionnaire items. Moreover, use of the percentage frequency distribution enhanced clarity of comparative responses to the variable indicators used in the study.

\section{RESULTS AND DISCUSSION}

Demographic characteristics of the respondents per view of the impact of hepatitis $B$ on the individual patient.

The results in table 4.1 encompasses presented data on the age, gender and religious background and marital statuses of the respondents by percentage distributions across the population interviewed. The response rate was good. A total of 40 questionnaires were administered to people living with hepatitis B. Out of this number, 36 respondents returned their questionnaires. From table 4.1 Muslims had the highest percentage of (about 63\%). The data on Table 4.1 indicates that majority of the respondents were Muslims because they dominate the Christians and Traditional worshipers' population in Ejura-Sekyedumasi District as stated earlier in the District profile. Taking into account the percentage respondents to the numbers representing the various religious backgrounds in the study population, it would be observed that a higher percentage of the Muslim respondents were found to have responded. Some reasons that could come up to explain this phenomenon include; Islam has made provision for multiple marriages among its followers. This means that a whole household could end up being infected with the virus, should it affect one person. Coupled with this, the low standard of education which does not encourage pre-screening among the Muslim community is a serious contributing factor. It must also be mentioned that with reference to the fact that in regions of high endemicity, $\mathrm{HBV}$ is mainly contracted at birth or early childhood [5], multiple marriage among Muslims could be a perfect precedence to the spread of the HBV within the district under study, therefore the subsequent effect. From table 4.1, 19 respondents representing $52.8 \%$ were not married. This might mean that because most energetic people have lots of contact 
Benjamin Makimilua Tiimub et al., EAS J Parasitol Infect Dis; Vol-2, Iss-5 (Sep-Oct, 2020): 60-76

with people, they are more prone to the infection than

and this represents $13.9 \%$ of the study population.

the married people. Only 5 respondents were divorced

Table-4.1 Age, sex, marital status and religion of the respondents

\begin{tabular}{|l|l|c|c|c|c|}
\hline $\begin{array}{l}\text { Response } \\
\text { Age of respondents }\end{array}$ & Frequency & Percent & Valid Percent & Cumulative Percent \\
\hline \multirow{5}{*}{ Valid } & $19-24$ & 5 & 13.9 & 13.9 & 13.9 \\
\cline { 2 - 6 } & $25-30$ & 19 & 52.8 & 52.8 & 66.7 \\
\cline { 2 - 6 } & 30 above & 12 & 33.3 & 33.3 & 100.0 \\
\cline { 2 - 6 } & Total & 36 & 100.0 & 100.0 & C\% \\
\hline Sex of respondents & $\mathrm{F}$ & $\%$ & $\mathrm{~V} \%$ & 41.7 \\
\hline Male & 15 & 41.7 & 41.7 & 100 \\
\hline Female & 21 & 58.3 & 58.3 & $\mathrm{C} \%$ \\
\hline Total & 36 & 100 & 100 & 33.3 \\
\hline Marital status of respondents & $\mathrm{F}$ & $\%$ & $\mathrm{~V} \%$ & 86.1 \\
\hline Married & 11 & 33.3 & 33.3 & 100 \\
\hline Single & 23 & 52.8 & 52.8 & \\
\hline Divorced & 2 & 13.9 & 13.9 & \\
\hline Total & 36 & 100 & 100 & \\
\hline Religion of respondents & $\mathrm{F}$ & $\%$ & $\mathrm{~V} \%$ & \\
\hline Christianity & 11 & 30.6 & 30.6 & \\
\hline Islam & 23 & 63.9 & 63.9 & \\
\hline Traditional & 2 & 5.6 & 5.6 & 100 \\
\hline Total & 36 & 100 & 100 & \\
\hline
\end{tabular}

Table-4.2: Living conditions of respondents infected with HBV (I) Ejura-Sekyedumasi

\begin{tabular}{|c|c|c|c|c|}
\hline $\begin{array}{l}\% \text { of respondents who can } \\
\text { afford medication }\end{array}$ & $\begin{array}{l}\text { Frequency } \\
\text { (F) }\end{array}$ & $\begin{array}{l}\text { Percent } \\
(\%)\end{array}$ & $\begin{array}{c}\text { Valid Percent } \\
(\text { V\%) }\end{array}$ & $\begin{array}{c}\text { Cumulative } \\
\text { Percent }(\mathbf{C} \%) \\
\end{array}$ \\
\hline \multirow{3}{*}{ Valid } & 15 & 41.7 & 41.7 & 41.7 \\
\hline & 21 & 58.3 & 58.3 & 100.0 \\
\hline & 36 & 100.0 & 100.0 & \\
\hline State of respondents' physical condition & $\mathrm{F}$ & $\%$ & $\mathrm{~V} \%$ & $\mathrm{C} \%$ \\
\hline very good & 2 & 5.6 & 5.6 & 5.6 \\
\hline Good & 12 & 33.3 & 33.3 & 38.9 \\
\hline Poor & 18 & 50.0 & 50.0 & 88.9 \\
\hline Very poor & 4 & 11.1 & 11.1 & 100.0 \\
\hline Total & 36 & 100.0 & 100.0 & \\
\hline $\begin{array}{l}\text { Number of meals HBV patients can afford in daily } \\
\text { before HBV infection }\end{array}$ & $\mathrm{F}$ & $\%$ & $\mathrm{~V} \%$ & $\mathrm{C} \%$ \\
\hline Three & 28 & 77.8 & 77.8 & 77.8 \\
\hline Two & 8 & 22.2 & 22.2 & 100.0 \\
\hline Total & 36 & 100.0 & 100.0 & \\
\hline $\begin{array}{l}\text { Number of meals HBV patients can afford daily } \\
\text { after infection }\end{array}$ & $\mathrm{F}$ & $\%$ & $\mathrm{~V} \%$ & $\mathrm{C} \%$ \\
\hline Three & 16 & 44.4 & 44.4 & 44.4 \\
\hline Two & 9 & 52.8 & 52.8 & 97.2 \\
\hline One & 1 & 2.8 & 2.8 & 100.0 \\
\hline Total & 36 & 100.0 & 100.0 & \\
\hline $\begin{array}{l}\text { Number of respondents able to pay utility bills } \\
\text { regularly before infection. }\end{array}$ & $\mathrm{F}$ & $\%$ & $\mathrm{~V} \%$ & $\mathrm{C} \%$ \\
\hline \multirow{2}{*}{$\begin{array}{cc}\text { Valid } & \text { Yes } \\
& \text { No }\end{array}$} & 30 & 83.3 & 30.6 & 30.6 \\
\hline & 6 & 16.7 & 69.4 & 100.0 \\
\hline $\begin{array}{c}\text { No } \\
\text { Total }\end{array}$ & 36 & 100.0 & 100.0 & \\
\hline $\begin{array}{l}\text { Number of respondents able to pay utility bills } \\
\text { regularly after infection }\end{array}$ & $\mathrm{F}$ & $\%$ & V\% & $\mathrm{C} \%$ \\
\hline \multirow{2}{*}{$\begin{array}{ll}\text { Yes } \\
\text { No }\end{array}$} & 15 & 41.7 & 41.7 & 41.7 \\
\hline & 21 & 58.3 & 58.3 & 100.0 \\
\hline Total & 36 & 100.0 & 100.0 & \\
\hline
\end{tabular}




\section{Living condition of the respondents infected with} hepatitis $B$

The data on table 4.2 presents the feedback on the state of living conditions of various respondents engaged in the survey ad HBV patients in the study areas following the key question on whether patients were able to afford medication per their current physical living conditions, afford a decent meal and also pay utility bills regularly before and after the HBV infection. The study reveals that living condition of respondent at the time of conducting research was not the best. About 21 respondents representing 58.3\% were not able to afford medication. The inability to afford medication has a very big impact on the life of the infected person. This means that there is the likelihood of the infection getting worse. The impact can be seen on table 4.2 The $41.7 \%$ of the respondents who are able to afford medication are doing it on the grounds that they can afford or they are supported. Approximately 12 respondents representing 33.3\% live in good physical condition.

The seriousness is seen as 18 respondents representing $50.0 \%$ were living in a poor physical condition. One of the effects of table 4.5 is what is seen in table 4.2. When people are not able to afford medication, the effect is poor physical condition. In table 4.2 the data comparing the eating periods reflected the time frequencies respondents were able to afford meals regularly before and after the HBV infection. A retrospective view clearly shows that there has been clear cut shift in the times respondent ate with respect to time. Before the infection most of them were eating three times in a day representing $77.8 \%$ with $22.2 \%$ eating twice a day. After the infection quite a number of them ate twice a day showing a decline in their regular eating frequencies. Table 4.2 further compared the ability of respondents to pay Bills regularly before and after HBV infection. Only $16.7 \%$ of the respondents were able to pay their bills regularly but this figure rose to $59.4 \%$ indicating the extent to which the respondents had been affected by the HBV infection. Respondent's inability to work due to HBV infection leads to their inability to pay their utility bills. This is clearly demonstrated in their expressed opinions in table 4.2. It generally been speculated and supported by scientific investigations that - many people living with chronic HBV infection remain undiagnosed until later stages where the impacts of the disease are usually so huge and negatively challenging on the individuals affected. Also, increasing testing and treatment rates form part of the strategy to respond to the WHO goal of eliminating viral hepatitis as a public health threat by 2030 [44]. However, achieving these ambitious targets is still largely dependent on finding efficient and cost-effective HBV control intervention and scale up strategies [45].

Relationship between patient and family as well as community members before and after $\mathrm{HBV}$ infection after mouth effects based of lifestyle changes

Table 4.3 presents data on the kind of relationship that existed between patient and family as well as community members before and after HBV infection and the after-mouth effects based on new life style changes in the Ejura-Sekyedumas district.

Table-4.3: Existing relationship between $\mathrm{HBV}$ patients with others before and after infection after mouth effects in the Ejura-Sekyedumasi district

\begin{tabular}{|l|l|l|l|l|}
\hline $\begin{array}{l}\text { Valid responses on relationship between family members and } \\
\text { HBV patients with others before infection }\end{array}$ & Frequency & Percent & Valid Percent & $\begin{array}{l}\text { Cumulative } \\
\text { Percent }\end{array}$ \\
\hline Very cordial & 22 & 61.1 & 61.1 & 61.1 \\
\hline Cordial & 12 & 33.3 & 33.3 & 94.4 \\
\hline Poor & 2 & 5.6 & 5.6 & 100.0 \\
\hline Total & 36 & 100.00 & 100.0 & \\
\hline $\begin{array}{l}\text { Valid responses on relationship between family members and patients } \\
\text { after HBV infection }\end{array}$ & F & $\%$ & V\% & C\% \\
\hline Very cordial & 8 & 22.2 & 22.2 & 22.2 \\
\hline Cordial & 10 & 27.8 & 27.8 & 50.0 \\
\hline Poor & 14 & 38.9 & 38.9 & 88.9 \\
\hline Very poor & 4 & 11.1 & 11.1 & 100.0 \\
\hline Total & 36 & 100.0 & 100.0 & \\
\hline $\begin{array}{l}\text { Valid responses on the relationship between Patients and other } \\
\text { community members before HBV infection }\end{array}$ & $\mathrm{F}$ & $\%$ & $\mathrm{~V} \%$ & $\mathrm{C} \%$ \\
\hline Very cordial & 16 & 44.4 & 44.4 & 44.4 \\
\hline Cordial & 18 & 50 & 50 & 94.4 \\
\hline Poor & 2 & 5.6 & 5.6 & 100.0 \\
\hline Total & 36 & 100.0 & 100.0 & \\
\hline $\begin{array}{l}\text { Vali responses on relationship between patients and other community } \\
\text { members after HBV infection }\end{array}$ & $\mathrm{F}$ & $\%$ & V\% & C\% \\
\hline Very cordial & 9 & 12 & 33.3 & 33. \\
\hline Cordial & 15 & 41.7 & 41.7 & 25.0 \\
\hline Poor & 36 & 100.0 & 100.0 & 100.0 \\
\hline Total & & & \\
\hline
\end{tabular}


Twenty respondents representing $61 \%$ had a very good relationship with just 2 family members representing $5.6 \%$ having poor relationship with their family members before infection. From table 4.3 , the number of respondents having cordial relationship reduced from 22 to 8 after the $\mathrm{HBV}$ infection. It also shows that the number of respondents having poor relationship had risen from 2 to 14 . The rise represents $38.9 \%$. Again, 4 respondents consequently had very poor relationships with their family members as a result of the infection. The effect suffered by HBV patients on tables 4.3 further clearly displayed what was significantly glaring and profound is stigmatization. Eighteen respondents out of 36 intimated they were suffering from stigmatization, representing $50 \%$ of the population of infected individuals among the population of subjects reached in the survey. Neglect, isolation, insults, teases, accounted for $13.9 \%, 22.2 \%, 5.6 \%$ and $8.3 \%$ respectively as some of the deleterious experiences the hepatitis B patients go through. Table 4.3 further presents the comparative relationship between respondents before and after the HBV infection - revealing that about $44.4 \%$ patients were having cordial relationship with their community members before the infection but the cordiality dwindled drastically to $25 \%$ after they got infected. That is the extent to which the infection affected decent relationships in the Ejura-Sekyedumasi district.

Neglect teases and isolation or social discrimination have jointed demonstrated to be detrimental to the welfare of HBV patients since it has immensely affected their social development status at many work places [19]. Whooping stigma against HBV carriers has either banned their progress at work or limited individual participation in communal works, and relegated their confidence at maintaining effective cordial relationships among families and members of traditionally oriented communities as well as seeking pleasures through new environmental acquaintances [46]. Recently, there has been discrimination in everyday life against rural migrant workers in Beijing who were HVB carriers [47].

\section{The type of occupations HBV infected patients engaged in}

Table 4.4 presents data on the types of occupations engaged by HBV patients before and after infection and the after-mouth effects, based on kind changes in working conditions of affected subjects and the reasons advanced for risking to be dismissed from their jobs in the Ejura-Sekyedumas district. It is clearly demonstrated that occupationally, the working population was dominated by traders and farmers at $38.9 \%$ and $33.3 \%$ respectively, and followed by government workers and artisans at $8.3 \%$ each. Students constituted the least $(2.8 \%)$ of the population respondents who never worked before getting HBV infection in the district. Valid responses by subjects whose work status or condition might have changed due to $\mathrm{HBV}$ infection clearly revealed $83.2 \%$ majority of them were still on the same job status despite living with HBV. Virtually a smaller same level fraction of infected individuals $(5.6 \%)$ was paired among artisan/trading, farming/trading and company work/trading respectively on their job scales as HBV patients (Table 4.4). Stigmatization featured strongly as the hotspot reason why about $61.1 \%$ significant majority of the HVB workers may voluntarily resign or get dismissed from government jobs especially. Also, fear of cross infection constituted $22.2 \%$ and deterioration or emaciation and debilitation accounted for $16.6 \%$ of the entire HBV patients who risked losing their jobs in the district.

Stigmatization creates an unnecessary culture of secrecy and silence based on ignorance and fear of victimization on the part of HVB patients who may have to seek frequent medical attention and be absent from work or unable to actively participate in stringent work schedules [19]. This may increase the risk of infected workers been laid off from their jobs or compel them opt for resignation due to inadequate medical attention especially in resource limited settings [48].

However, interventions that have been generally recommended towards effective management of HBV in stigma prone settings by various schools of thought include some valid initiatives such as:

i. Provision of educational opportunities in health care settings, in the individual's own language, can be valuable to inform patients of the importance of symptoms, treatment, follow-up, prevention and social stigma [49].

ii. improving knowledge regarding the potential for silent complications, and understanding treatment could enhance willingness to access healthcare and reduce fatalism [50];

iii. developing positive coping strategies may include seeking encouragement from spiritual leaders and open dialogue with family members [46];

iv. lifestyle modifications can be helpful, such as reduced intake of alcohol and fatty foods [51]; and

v. Combating barriers to interventions (example: remote location, lack of internet access, language barriers et cetera) by NGOs, health promotion and community development partners who ought to jointly mount the appropriate actions [49].

\section{Financial status of $\mathrm{HBV}$ patients in Ejura- Sekyedumasi District}

The financial situational analyses of $\mathrm{HBV}$ patients, based on current earnings and their abilities to save money before and after been infected with HBV is captured in table 4.5. From table 4.5 four respondents representing $11.1 \%$ had a very highly secured financial status before infection. The number reduced to two 
respondents after the infection representing $5.6 \%$. Majority of respondents represented by a frequency of 18 and corresponding $50 \%$ holistically assessed their financial status as high enough before the $\mathrm{HBV}$ infection. Respondents with low financial status were 3, corresponding to $8.3 \%$ before the $\mathrm{HBV}$ infection.
However, 18 respondents representing $50 \%$ experienced low financial status after the infection. Low financial standing served as the militant reason why respondents were unable to pay their bills regularly. Table 4.5 further shows the distribution of respondents who were able to save enough money before and after infection.

Table-4.4: Occupations of HBV patients with after-mouth effects of changes in working conditions and possible reasons for dismissals in the Ejura-Sekyedumas district.

\begin{tabular}{|l|l|l|l|l|}
\hline $\begin{array}{l}\text { Valid response on the type of works performed by HBV } \\
\text { patients before infection }\end{array}$ & Frequency & Percent & $\begin{array}{l}\text { Valid } \\
\text { percent }\end{array}$ & $\begin{array}{l}\text { Cumulative } \\
\text { percent }\end{array}$ \\
\hline Government work & 3 & 8.3 & 8.3 & 8.3 \\
\hline Artisan & 3 & 8.3 & 8.3 & 16.7 \\
\hline Farming & 12 & 33.3 & 33.3 & 50.0 \\
\hline Trading & 14 & 38.9 & 38.9 & 88.9 \\
\hline Student & 1 & 2.8 & 2.8 & 91.7 \\
\hline Others & 3 & 8.3 & 8.3 & 100.0 \\
\hline Total & 36 & 100.0 & 100.0 & \\
\hline $\begin{array}{l}\text { Valid responses on subjects whose work status or condition } \\
\text { have changed due to HBV infection }\end{array}$ & $\mathrm{F}$ & $\%$ & V\% & C\% \\
\hline Artisan/Trading & 2 & 5.6 & 5.6 & 5.6 \\
\hline Farming/Trading & 2 & 5.6 & 5.6 & 11.2 \\
\hline Company work/Trading & 2 & 5.6 & 5.6 & 16.8 \\
\hline Same work & 30 & 83.2 & 83.2 & 100.0 \\
\hline Total & 36 & 100.0 & 100.0 & \\
\hline $\begin{array}{l}\text { Valid responses on possible reasons why HBV patients may } \\
\text { resign or be dismissed from government work especially. }\end{array}$ & $\mathrm{F}$ & $\%$ & V\% & C\% \\
\hline Stigmatization & 22 & 61.1 & 61.1 & 61.1 \\
\hline Fear of cross infection & 8 & 22.2 & 22.2 & 83.3 \\
\hline Deterioration, emaciation and debilitation & 6 & 16.6 & 16.6 & 100.0 \\
\hline Total & 36 & 100.0 & 100.0 & \\
\hline
\end{tabular}

Table-4.5: Financial situational analysis of HBV patients based on current earnings, and their abilities to save or otherwise before and after infection.

\begin{tabular}{|l|l|l|l|l|}
\hline $\begin{array}{l}\text { Valid response on financial status of HBV patients } \\
\text { before infection }\end{array}$ & Frequency & Percent & $\begin{array}{l}\text { Valid } \\
\text { percent }\end{array}$ & $\begin{array}{l}\text { Cumulative } \\
\text { percent }\end{array}$ \\
\hline Very high & 4 & 11.1 & 11.1 & 11.1 \\
\hline High & 18 & 50.0 & 50.0 & 61.1 \\
\hline Average & 11 & 30.6 & 30.6 & 91.7 \\
\hline Low & 4 & 8.3 & 8.3 & 100.0 \\
\hline Total & 36 & 100.0 & 11.0 & \\
\hline $\begin{array}{l}\text { Valid response on financial status of HBV patients after } \\
\text { infection }\end{array}$ & $\mathrm{F}$ & $\%$ & $\mathrm{~V} \%$ & $\mathrm{C} \%$ \\
\hline High & 2 & 5.6 & 5.6 & 5.6 \\
\hline Average & 16 & 44.4 & 44.4 & 50.0 \\
\hline Low & 18 & 50.0 & 50.0 & 100.0 \\
\hline Total & 36 & 100.0 & 100.0 & \\
\hline $\begin{array}{l}\text { Valid responses on the ability of HBV patients to save } \\
\text { money before HBV infection }\end{array}$ & $\mathrm{F}$ & $\%$ & $\mathrm{~V} \%$ & $\mathrm{C} \%$ \\
\hline Yes & 31 & 86.1 & 86.1 & 86.1 \\
\hline No & 5 & 13.9 & 13.9 & 100.0 \\
\hline Total & 36 & 100.0 & 100.0 & \\
\hline $\begin{array}{l}\text { Valid responses on the ability of HBV patients to save } \\
\text { money after HBV infection }\end{array}$ & $\mathrm{F}$ & $\%$ & V\% & $\mathrm{C} \%$ \\
\hline Yes & 7 & & & 19.6 \\
\hline No & 29 & 80.6 & 80.6 & 100.0 \\
\hline Total & 36 & 100.0 & 100.0 & \\
\hline
\end{tabular}

Significantly, 31 respondents representing $86.1 \%$ were able to save something regardless how meagre it was. Before infection, only $5 \%$ of the respondents representing only $13.9 \%$ intimated they were eventually unable to save any money. This figure drastically change with regards to the number of 
respondents who were able to save and those unable. After infection, respondents unable to save outweighed those who could save. Those saving measured up to $19.4 \%$ while those unable measured up to $80.6 \%$ after HVB infection.

This observation corroborates with recent analyses in support of the view that chronic HBV patients due to their reduced immunity and ineffective working habits have low earnings with high medical expenditures which often exacerbate their financial statuses and impact negatively on them and their caretaking families who gradually experience lower living standards [52, 19, 48]. People living with HBV face numerous challenges, including disease progression, employment related difficulties, and increased medical expenses. The relationship between HBV victims' daily life suffering and poverty associated with HBV-related employment changes has not been fully examined even though the situational analyses reveals existent huge hardships among Japanese HBV patients [53, 54]. Much of the Japanese studies were structured around 7 cardinal aspects: intention to work, lack of understanding of HBV in the workplace, inability to buy life insurance, burden due to medical expenses, life failure, dissatisfaction with the system, and wishing for life balance. The quantitative analyses generally showed significant positive correlations between daily life suffering and liver cancer (odds ratio [OR] 1.47, 95\% confidence interval $[\mathrm{CI}]: \quad 1.00-2.17, p<0.05)$, being a part-time/casual employee (OR 1.46, 95\% CI: 1.11-1.92 $p<0.01$ ), and an income below the national average $(p<0.01)$ [53].

Effect of HBV infection on the community based on cross examination of patients' ability to work subject to fear of other community members getting cross infected

Table 4.6 presents information on the ability of HBV patients to work, based on the effect the disease casts on the entire community and further on if patients could participate in communal labour subject to fear of other community members getting cross infected before and after contracting the disease. From table 4.6, the entire respondents were able to work hard before HBV infection but contrarily, most respondents representing up to $61.1 \%$ were unable to work hard after the infection. Quite a significant number of respondents were able to work hard after infection. This may be due to either advice from their doctors or that they want to work hard enough to maintain their body shapes.

Table-4.6: Responses on ability of HBV patients to work/participate in communal labour subject to fear of other community members getting cross infected with the disease.

\begin{tabular}{|l|l|l|l|l|}
\hline Valid responses on ability to work before HBV infection & Frequency & Percent & $\begin{array}{l}\text { Valid } \\
\text { percent }\end{array}$ & $\begin{array}{l}\text { Cumulative } \\
\text { percent }\end{array}$ \\
\hline Yes & 36 & 100 & 100 & 100 \\
\hline $\begin{array}{l}\text { No } \\
\text { Total }\end{array}$ & $\begin{array}{l}\text { Nil } \\
36\end{array}$ & $\begin{array}{l}\text { Nil } \\
100\end{array}$ & $\begin{array}{l}\text { Nil } \\
100\end{array}$ & \\
\hline $\begin{array}{l}\text { Valid responses on the patients' ability to attend communal } \\
\text { labour after HBV infection }\end{array}$ & F & $\%$ & V\% & C\% \\
\hline Yes & 27 & 75.0 & 75.0 & 75.0 \\
\hline No & 9 & 25.0 & 25.0 & 100.0 \\
\hline Total & 36 & 100 & 100 & \\
\hline $\begin{array}{l}\text { Valid responses on the patients' ability to attend communal } \\
\text { labour after HBV infection. }\end{array}$ & F & $\%$ & V\% & C\% \\
\hline Yes & 15 & 41.7 & 41.7 & 41.7 \\
\hline No & 21 & 58.3 & 58.3 & 100.0 \\
\hline Total & 36 & 100.0 & 100.0 & \\
\hline $\begin{array}{l}\text { Valid responses on fear possibility of community members being } \\
\text { cross infected by HBV patients in the course of communa } \\
\text { labour. }\end{array}$ & & $\%$ & V\% & C\% \\
\hline Yes & 34 & & & \\
\hline No & 2 & 94.4 & 94.4 & 94.4 \\
\hline Total & 36 & 5.6 & 5.6 & 100.0 \\
\hline
\end{tabular}

In table 4.2 further, $77.8 \%$ of the respondents had already expressed their affordability of three-square meals in a day and this figure rose drastically. Also, only $44.4 \%$ were able to afford three square meals to boost their energy sources. This invariably meant that, eating well will definitely strength them towards hard work. Being able to work hard after HBV infection depends on certain factors such as seeking good regular medication, improving eating habits and taking enough rest between working intervals [48]. Improving access to health care and patronizing good nutrition were sound interventions that also prolonged the lives of chronic hepatitis B carriers among migrant Chinese populations [55]. Table 4.6 data further clarifies issues about respondent's ability to attend communal labour. As many as 27 respondents representing $75 \%$ were able to attend communal labour before infection. Nine respondents representing $25 \%$ were not able to attend communal labour. The statistics indicates that, 21 respondents representing $41.7 \%$ attend communal labour. The number is high because communal labour is compulsory and failure to attend often attracts a fine in 
these communities. Much as $58.3 \%$ of respondents does not attend communal labour after infection. And this explains the extent to which the infection has curtailed their effective participation in communal labour, the spirit of togetherness as bonded by virtues which are core values in the Ghanaian settings. Communal labour is one of the social activities that bring indigenes together to achieve such core values (giving and sharing of talents and resources for mutual benefits) of a society. Fear became eminent in the research as about $94.4 \%$ revealed that people are afraid of getting the infection although just two respondents constituting $5.6 \%$ disagreed with this assertion. Jones et al., recently intimated that adapting mixed-cultural methods or approaches to understanding perceptions of hepatitis B and hepatocellular carcinoma among ethnically diverse Black communities in South Florida could reduce irrelevant barriers to social event participation by HBV infected patients and eventually improve their work habits [52]. This goal is achievable when integrated with a strong advocacy against social stigmatization of HBV patients once it becomes part of important national focal health policy agenda and solemnized by concerned social development partners globally [20].

\section{CONCLUSIONS}

The findings eventually added up to the baseline data banks which prove that Hepatitis is one of the most common infectious diseases of the world entangling about two billion people including an estimated 400 million chronically infected cases (with 350 million people worldwide carrying the Hepatitis B virus, and 170 million Hepatitis C) [56]. Based on figures from 2015, the World Health Organization has already hit global targets to reduce new cases of viral hepatitis by 90 percent and is set to achieve 80 percent treatment coverage for chronic hepatitis $\mathrm{B}$ and $\mathrm{C}$ patients by 2030 . Infection by HBV cause serious mortality, mobility and financial burden and are thus a major global health problem [57]. Few studies have previously indicated the high prevalence of $\mathrm{HBV}$ in Ghana. The effects of hepatitis B on the individual patient and the community cannot be overemphasized since the study has provided enough information on the effect the disease has on the individual patient and the community (Ejura-Sekyedumasi).

For the individual, it ranges from stigmatization, inability to afford three square meals, inability to pay utility bills, dismissal from work, relationships problems with family members, neglect, and inability to save and so on. From the community, HBV patients are unable to attend communal labour and their inability to pay bills affects their productivity. The number of identified people living with the infection is very high among the active population, which mainly subject the infected individuals to some undesirable stigmatization in the community.
There seems to be lack of education about the mode of transmission, let alone its effects. The findings indicated that approximately $61.1 \%$ of respondents were stigmatized. Again, about $61 \%$ of the respondents were unable to work hard enough to earn better income after the infection. The number of single respondents was more than the married and the divorced ones. This meant majority of the infected individuals were unmarried, further suggesting that single people are more vulnerable to the HBV infection which is concurrently attributable to lifestyles and other social factors.

\section{RECOMMENDATION}

i. The Ghana Health Service through its community/public health interventions programs should partner Religious institutions especially Muslims and Christians to educate their members on the effect of hepatitis B.

ii. Health care providers and state media institutions should routinely educate the community on the need to welcome people living with the infection and not to stigmatize them.

iii. Religious organization should promote premarital counselling/test on HBV before approving marriage relationships so that the necessary precautions will be adopted to reduce the negative effect on married couples.

iv. There should be mass vaccination by health development partners as part of WHO surveillance strategies to control HBV cross infections among growing populations in various communities.

v. People living with HBV should be advised to stop sharing pins, needles and other sharp objects with other individuals and seek frequent medical attention.

vi. People living with the HBV infection should be educated to eat well at least three times in a day (fatty foods should be avoided as much as possible since it pressurizes the liver).

vii. Infected persons should be educated to do a lot of exercises and avoid overworking themselves.

viii. Infected person should not be dismissed but rather encouraged to work harder in order

ix. To get money to afford medication.

\section{ACKNOWLEDGEMENT}

The authors are extremely grateful to $\mathrm{Mr}$. Beloved Mensah Dzomeku of CSIR Crops Research Institute, Kumasi for his sacrifices, guidance and the fatherly advice without which this study may not have been successfully executed.

\section{Authors Contributions}

Benjamin, Beloved, Gideon, Richard, Foster, Joan and Isaac were partners in the main research conduction whereas Benjamin provided funds and 
leadership guidance with Gideon who further cross examined the questionnaires for pretesting and actual survey. Benjamin also improved the discussion while Ernestina and Joan updated references and reviewed aspects of the literature. Elisha edited the data tables and abstract. All authors co-edited the article.

\section{REFERENCES}

1. Tsukuda, S., \& Watashi, K. (2020). Hepatitis B virus biology and life cycle. Antiviral Research, 104925.

2. Kahn, A. (2018). Hepatitis B: Transmission, Risk factors, Symptoms, Diagnosis, Treatments, Complications, Prevention. Medically reviewed by Judith Marcin, M.D. Updated on September 28, 2018 Healthline Media. University of Illinois.

3. Global Hepatitis Report [GHR]. (2017). World Health Organization; Geneva.

4. Dun-Dery, F., Adokiya, M.N., Walana, W., Yirkyio, E., Ziem, J.B. (2017). Assessing the knowledge of expectant mothers on mother-tochild transmission of viral hepatitis B in Upper West region of Ghana. BMC Infect Dis. 17:416. 28606057.

5. WHO. (2009). "Hepatitis B"

http://www.who:int/mediaconter/facsheet/fs204/en/ index,

html.)http://www.who.int/mediacenter/factsheets/fs 204/en/index.html.Retrieved

6. Ghana Health Service [GHS]. (2017). Annual Report, 2016. Accra: Ghana Health Service; 2017.

7. Agyeman, A. A., \& Ofori-Asenso, R. (2016). Prevalence of HIV and hepatitis B coinfection in Ghana: a systematic review and meta- analysis. AIDS Res Ther. May 17; 13:23.

8. Kennard, J. (2020). How Hepatitis Is Transmitted. Medically reviewed by Priyanka Chugh, MD on January 28, 2020. Verywellhealth (Doltash).

9. Shimakawa, Y. (2015). Establishment of chronic hepatitis B infection as a risk factor for persistent viral replication, liver fibrosis and hepatocellular carcinoma in The Gambia, West Africa. $\mathrm{PhD}$ Thesis, London School of Hygiene \& Tropical Medicine.

10. Schweitzer, A., HorJ, J., Mikolajczyk, R.T., Krause, G., Ott, J.J. (2015). Estimations of worldwide prevalence of chronic hepatitis B virus infection: a systematic review of data published between 1965 and 2013. Lancet. 386(No. 10003):1546-1555.

11. Centre for Disease Control [CDC]. (2020). Viral Hepatitis: Hepatitis B Information. CDC 24/7: Saving Lives, Protecting People. Division of Viral Hepatitis, National Center for HIV/AIDS, Viral Hepatitis, STD, and TB Prevention. https://www.cdc.gov/hepatitis/HBV/perinatalxmtn. ht

12. Chauhan, V. (2020). Liver Cirrhosis-Symptoms, Causes, Ayurvedic Treatment. Planet Ayurveda, Punjab,

India. https://www.planetayurveda.com/liver-cirrhosistreatment/.

13. Abesig, J. Chen, Y., Wang, H., Sompo, F. M, and Wu, I. X. Y. (2019). Prevalence of viral hepatitis B in Ghana between 2015 and 2019: A systematic review and meta-analysis. PLoS One, 12;15(6): $\mathrm{e} 0234348$.

14. Osei, E., Lokpo, S. Y., \& Agboli, E. (2017). Seroprevalence of hepatitis $\mathrm{B}$ infection among blood donors in a secondary care hospital, Ghana (2014): a retrospective analysis. $B M C$ research notes, 10(1), 391.

15. Pido, B., \& Kagimu, M. (2005). Prevalence of Hepatitis B Virus (HBV) infection among Makerere.Med.J.1229-30.

16. Yambasu, E. E., Reid, A., Owiti, P., Manzi, M., Murray, M. J. S., \& Edwin, A. K. (2018). Hidden dangers-prevalence of blood borne pathogens, hepatitis B, C, HIV and syphilis, among blood donors in Sierra Leone in 2016: opportunities for improvement: a retrospective, cross-sectional study. The Pan African Medical Journal, 30.

17. Vento, S., Dzudzor, B, Cainelli, F., Tachi, K. (2018). Liver cirrhosis in sub-Saharan Africa: neglected, yet important. Lancet Glob Health. 6: e1060-e1061. pmid:30219314.

18. CDC. (2019). Vaccine (Shot) for Hepatitis B. Español: Hepatitis B. Saving Lives, Protecting People.

https://www.cdc.gov/vaccines/parents/diseases/hep b.html

19. Mokaya, J. (2018). Stigma around Hepatitis B Infection. KEMRI - Wellcome Trust -Stellenbosch University, Kenya.

20. Mokaya, J., McNaughton, A.L., Burbridge, L., Maponga, T., O'Hara, G., Andersson, M., Seeley, J., Matthews, P. C. (2018). A blind spot? Confronting the stigma of hepatitis B virus (HBV) infection - A systematic review. Wellcome Open Res:3:29.

21. Kane, M.A. (1996). Global status of hepatitis B immunization. Lancet. Ghana journal of Public Health; 348:696

22. World Health Organization [WHO]. (2015). Guidelines for the prevention, care and treatment of persons with chronic hepatitis B infection. Geneva.

23. Zidan, A., Scheuerlein, H., Schüle, S., Settmacher, U., Rauchfuss, F. (2012). Epidemiological pattern of hepatitis $\mathrm{B}$ and hepatitis $\mathrm{C}$ as etiological agents for hepatocellular carcinoma in Iran and worldwide. Hepat Mon, 12(10 HCC): e6894. pmid:2323386.

24. Ott, J. J., Stevens, G. A., Groeger, J., \& Wiersma, S. T. (2012). Global epidemiology of hepatitis B virus infection: new estimates of age-specific HBsAg seroprevalence and endemicity. Vaccine, 30(12), 2212-2219.

25. Li, X., Zheng, Y., Liau, A., Cai, B., Ye, D., Huang, F., ... \& Li, J. (2012). Hepatitis B virus infections and risk factors among the general population in 
Anhui Province, China: an epidemiological study. BMC public health, 12(1), 272.

26. Apiung, T., Ndanu, T.A., Mingle, J.A., Sagoe, K.W. (2017). Hepatitis B virus surface antigen and antibody markers in children at a major paediatric hospital after the pentavalent DTP-HBV-Hib vaccination. Ghana Med J. 51:13-9. pmid:28959067

27. Bauer, J. (2003). Co-Infection with hepatitis B and HIV increases men's risk of death from liver disease.(Infectious Diseases). $R N, 66(3), 97-98$.

28. Dongdem ,A.Z., Dzodzomenyo, M., Asmah, R. H., Nyarko, K. M., Nortey, P., Agyei , A., Adjei, D. N., Kenu, E., \& Adjei, A.A.(2016). Hepatitis B virus genotypes among chronic hepatitis $\mathrm{B}$ patients reporting at Korle-Bu teaching hospital, Accra, Ghana. Pan Afr Med J. 25 Suppl 1: 5. pmid:28210373.

29. Puri, P. (2014). Tackling the Hepatitis B disease burden in India. J Clin Exp Hepatol. 4: 312-319. pmid:25755578.

30. Yakasai, I.A., Ayyuba, R., Abubakar, I.S., Ibrahim, S.A. (2012). Sero-prevalence of hepatitis B virus infection and its risk factors among pregnant women attending antenatal clinic at Aminu Kano Teaching Hospital, Kano, Nigeria. J Basic Clin Reprod Sci.1: 49-55.

31. Nkrumah, B., Owusu, M., Frempong, H.O., Averu, P. (2011) Hepatitis B and C viral infections among blood donors from rural Ghana. Ghana Med J. 45:97-100. pmid:22282575.

32. Nejo, Y., Faneye, A. O., Olusola, B., Bakarey, S., Olayinka, A., Motayo, B., \& PERVI Study Group. (2018). Hepatitis B virus infection among sexually active individuals in Nigeria: a cross-sectional study. Pan Afr Med J, 30: 155. pmid:30455784

33. Merriam Webster. (2020). "Dane particle." Merriam-Webster.com Medical Dictionary, Merriam-Webster.

34. Kessler, D. A., \& Jimenez, A. (2019). Hepatitis B Virus Screening. In Transfusion Medicine and Hemostasis (pp. 73-76). Elsevier.

35. Daniel, C. (2020). Hepatitis B Surface Antigen Test (HBsAg). Test for Active or Chronic Hepatitis B. Medically reviewd by Robert Burkoff, April 2020. Verywellhealth (Doltish). https://www.verywellhealth.com/what-is-hbsag1759934.

36. Ajibawo, M. (2020). Hepatitis B may be contracted through deep kissing - Expert. PUNCH, August, 2020. Federal Medical Centre, Ebute Meta, Lagos.

37. Spearman, W., Ally, R., Apica, B., Awuku, Y., Cunha, L., Dusheiko, G., Gogela, N., Kasianides, C., Kew, ., Lam P. Lesi, O., Lohouès-Kouacou, M.J., Mbaye, P. S., Musabeyezu, E., Musau, B., Ojo, O., Rwegasha, J., Scholz, B., Shewaye, A. B., Tzeuton, C., \& Sonerup, M. W. (2017). Hepatitis B in sub-Saharan Africa: strategies to achieve the 2030 elimination targets. Lancet Gastroenterol Hepatol. 2: 900-909. pmid:29132759
38. Acheampong, J. W. (1991). The prevalence of hepatitis B surface antigen (HBsAg) among blood donors and jaundiced patients at Komfo Anokye Teaching Hospital. Ghana Med. J. 25:313-317.

39. Adjei, A. A., H. B. Armah, F. Gbagbo, W. K. Ampofo, I. K. Quaye, I. F. Hesse, and G. Mensah. (2006). Prevalence of human immunodeficiency virus, hepatitis $\mathrm{B}$ virus, hepatitis $\mathrm{C}$ virus and syphilis among prison inmates and officers at Nsawam and Accra, Ghana. J. Med. Microbiol.55:593-597.

40. Felman, A. (2017). Everything you need to know about cirrhosis. Medically reviewed by Daniel Murrell, M.D. December 5, 2017.

41. Bandopadhyay, M., Bharadwaj, M. (2020). Exosomal miRNAs in hepatitis B virus related liver disease: a new hope for biomarker. Gut Pathog 12, 23.

42. Blachier, M., Leleu, H., Peck-Radosavljevic, M., Valla, D.C., \& Roudot-Thoraval, F. (2013). The burden of liver disease in Europe: a review of available epidemiological data. $J$ Hepatol. 2013;58(Suppl 3):593-608.

43. Elliott, W. T. (2003). Critical Care Alert April 2003 "Warfarin Effectively Prevents Venous Thromboembolism (Pharmacology Watch).

44. Nayagam, S., Sicuri, E., Lemoine, M., Easterbrook, P., Conteh, L., Hallett, T. B., \& Thursz, M. (2017). Economic evaluations of $\mathrm{HBV}$ testing and treatment strategies and applicability to low and middle-income countries. BMC Infectious Diseases, 17(1), 692.

45. Barbosa, C., Smith, E.A., Hoerger, T.J., Fenlon, N., Schillie, S.F., Bradley, C., Murphy, T.V. (2014). Cost-effectiveness analysis of the National Perinatal Hepatitis B Prevention Program. Pediatrics, 133(2):243-53.

46. Cochrane, A., Collins, P., Horwood, J.P. (2016). Barriers and opportunities for hepatitis B testing and contact tracing in a UK Somali population: a qualitative study. Eur $J$ Public Health, 26(3):389-95.

47. Leng, A., Li, Y., Wangen, K. R., Nicholas, S., Maitland, E., \& Wang, J. (2016). Hepatitis B discrimination in everyday life by rural migrant workers in Beijing. Human vaccines \& immunotherapeutics, 12(5), 1164-1171.

48. World Health Organization. (2017). Global Hepatitis Programme. Global hepatitis report, 2017; 68.

49. Carabez, R. M., Swanner, J. A., Yoo, G. J., \& Ho, M. (2014). Knowledge and fears among Asian Americans chronically infected with hepatitis B. Journal of Cancer Education, 29(3), 522-528.

50. Blanas, D. A., Nichols, K., Bekele, M., Shankar, H., Bekele, S., Jandorf, L., ... \& Perumalswami, P. V. (2015). Adapting the Andersen model to a francophone West African immigrant population: hepatitis B screening and linkage to care in New York City. Journal of community health, 40(1), 
175-184.

51. Adjei C.A., Naab, F., Donkor, E.S. (2017). Beyond the diagnosis: a qualitative exploration of the experiences of persons with hepatitis $\mathrm{B}$ in the Accra Metropolis, Ghana. BMJ Open, 7(11): e017665. 10.1136/bmjopen-2017-017665

52. Jones, P., Soler, J., Solle, N.S., Martin, P., \& Kobetz, E. (2020). A mixed-methods approach to understanding perceptions of hepatitis $\mathrm{B}$ and hepatocellular carcinoma among ethnically diverse Black communities in South Florida. Cancer Causes \& Control. Springer Nature, Switzerland AG.

53. Oka, T., Enoki, H., Tokimoto, Y., Kawanishi, T., Minami, M., Okuizumi, T., \& Katahira, K. (2017). Employment-related difficulties and distressed living condition in patients with hepatitis B virus: A qualitative and quantitative study. BioMed Central Ltd. Part of Springer Nature, June,
2017.

54. Tatsuoka, S. (2015). Editorial: research on prejudice and discrimination against viral hepatitis patients. Gakushuin Houmu Kenkyu. 9:1-15.

55. Vedio, A., Liu, E.Z.H, Lee, A.C.K., \& Salway, S. (2017): Improving access to health care for chronic hepatitis B among migrant Chinese populations: A systematic mixed methods review of barriers and enablers. J Viral Hepat, 24(7):526-40.

56. Simonsen, L., Kane, A., Lloyd, J., Zaffran, M., \& Kane, M. (1999). Unsafe injections in the developing world and transmission of bloodborne pathogens: a review. Bulletin of the World Health Organization, 77(10), 789.

57. Longbin, L. (2018). China launches "first-in-class" drug to battle chronic hepatitis B. CEO and president of Genova Inc. and general manager of Genova Biotech (Qingdao) Co. Ltd.

\section{APPENDIX: Survey instrument}

The aim of the project is to add to a body of knowledge to identifying the impact of hepatitis B infection on the individual and the community in partial fulfilment of Bachelor of Science Degree award in integrated science. All information will be held anonymously confidential.

\section{Instruction}

Please answer all questions. Kindly tick in the box and fill in the space provided below. Please, DO NOT write your name on any part of the questionnaire.

\section{A. BIOGRAGPHY DATA}

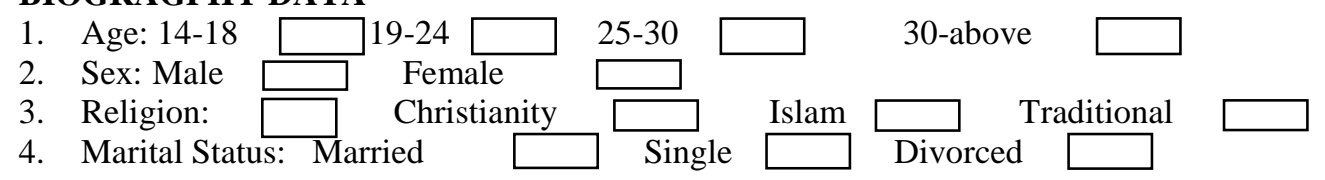

B. LIVING CONDITION (HEALTH STATUS)

5. Are you able to afford medication? Yes

6. What is your state of physical condition?

Very good $\square$ good $\square$ poor $\square$ very poor

7. How many meals were you able to afford in a day before the infection? Three $\square$ Two $\square$ One

8. How many meals are you able to afford in a day after the infection Three $\square$ Two $\square$ One $\square$

9. Were you able to pay your utility bills regularly before infection? Yes 10. Are you able to pay your utility bills regularly after the infection? Yes
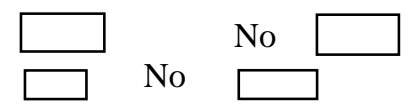

C. RELATIONSHIP

11. Relationship between patient and family members before infection: Very Cordial $\square$ Cordial $\square$ Poor $\square$ Very poor

12. Relationship between patient and family after infection: Very Cordial

$$
\text { Very poor }
$$

13. If poor or very poor what has changed? Specify current relation (Tick as many as are applicable) Stigmatized $\square$ Neglected Isolated $\square$ Insulted Laughed at $\square$ Others specify

14. What is the relationship between patient and the members in the community before infection? Very Cordial Cordial Very Poor

15. What is the relationship between patient and members in the community after infection? (Tick as many as applicable)

Very Cordial Stigmatized

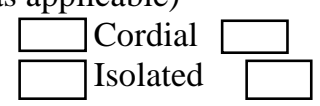

Poor
Very Poor 


\section{TYPE OF WORK}

16. What type of work were you doing before infection?

Government Worker $\square$ Artisan $\square$ Farming $\square$ Trading $\square$ Student $\square$ Others specify:

17. What type of work are you doing after infection? Same work

18. If work had changed specify: From ..................... to ....

19. If stopped working, why?

20. If dismissed why?

Stigmatized $\square$ Fear of infecting others $\square$ Deterioration of immune system

E. FINANCIAL STATUS

21. Financial status before infection Very High

$$
\text { High }
$$

Average

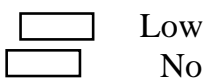

22. Were you able to save before infection? Yes

23. Were you able to work hard before infection? Yes

24. Are you able to work hard after infection? Yes

$\square$ No

F. EFFECTS ON THE COMMUNITY

25. Were you able to attend community functions and play key role(s) before infection? Yes

26 Are you able to attend communal labour regularly after infection? Yes

27 Are people in your community afraid of getting the infection? Yes 